The Orthodox Church in the Arab World $700-1700$ 



\title{
The Orthodox
}

Church in THE

Arab World

$700-1700$

An Anthology of Sources

\author{
E D I T E D B Y \\ Samuel Noble and Alexander Treiger
}

F O R E W O R D B Y

Metropolitan Ephrem (Kyriakos)

A Publication in the Orthodox Christian Series

N I U Press, DeKalb, IL 
(C) 2014 by Northern Illinois University Press

Published by the Northern Illinois University Press, DeKalb, Illinois 60115

Manufactured in the United States using acid-free paper.

All Rights Reserved

Design by Shaun Allshouse

Library of Congress Cataloging-in-Publication Data

The Orthodox church in the Arab world, 700-1700: an anthology of sources / edited by Samuel Noble and Alexander Treiger ; foreword by Metropolitan Ephrem (Kyriakos).

pages $\mathrm{cm}$

Includes bibliographical references and index.

ISBN 978-0-87580-701-0 (pbk.) — ISBN 978-1-60909-155-2 (e-book)

1. Orthodox Eastern Church-Arab countries-History-Sources. 2. Orthodox Eastern

Church-Doctrines. I. Noble, Samuel, editor of compilation. II.

Treiger, Alexander, editor of compilation.

BX250.0674 2014

$281.90917^{\prime} 4927-\mathrm{dc} 23$

2013041734 